Article

\title{
The Impact of Corruption, Economic Freedom and Urbanization on Economic Development: Western Balkans versus EU-27
}

\author{
Nerajda Feruni ${ }^{1}$, Eglantina Hysa ${ }^{1} \oplus$, Mirela Panait ${ }^{2, *} \oplus$, Irina Gabriela Rădulescu ${ }^{3}$ \\ and Alina Brezoi ${ }^{3}$ \\ 1 Department of Economics, Epoka University, 1032 Tirana, Albania; nferuni15@epoka.edu.al (N.F.); \\ ehysa@epoka.edu.al (E.H.) \\ 2 Department of Cybernetics, Economic Informatics, Finance and Accounting, Petroleum-Gas University \\ of Ploiești, 100680 Ploiești, Romania \\ 3 Department of Business Administration, Petroleum-Gas University of Ploiești, 100680 Ploiești, Romania; \\ iri_radulescu@yahoo.com (I.G.R.); alina_brezoi@yahoo.com (A.B.) \\ * Correspondence: mirela.matei@upg-ploiesti.ro
}

Received: 28 October 2020; Accepted: 20 November 2020; Published: 22 November 2020

\begin{abstract}
The topic of economic development has been addressed in recent decades from more and more points of view in order to identify the factors with significant impact on this phenomenon. Identifying the factors and measuring their impact on economic development are essential starting points for adopting the necessary public policies. Similar types of research for the Western Balkan countries and comparative analyses between the Western Balkans and the European Union countries are limited in number. Hence, the main purpose of this paper is to empirically test the impact of corruption, economic freedom, and urbanization on the economic development for both the Western Balkan countries and the EU countries for the period 2009-2018 to provide a comparative analysis for these two groups. The corruption perception index, economic freedom index, and urban population growth are chosen as independent variables, whereas the dependent variable of the human development index (HDI) represents economic development. Using the Random Effects model, which falls under the Panel Generalized Least Square method, the empirical analysis suggests that corruption has a negative impact on economic development, while economic freedom and urbanization have a positive impact on the economic development for both groups of countries. However, the impact of corruption is more destructive in the Western Balkans, and they appear to benefit more from economic freedom and urbanization as compared to the EU countries. Whether the impact of the chosen independent variables is restricted to any component of the HDI in particular is left open for further studies in the future, though the results of this paper are highly significant and in accordance with the reviewed literature.
\end{abstract}

Keywords: economic development; corruption; economic freedom; urbanization; random effect

\section{Introduction}

Development and growth represent the binomial that goes side by side in the process of a country's advancement. Economic growth is considered a single-dimensional phenomenon, as it focuses only on the income of the people of the country. On the contrary, economic development is considered a multidimensional phenomenon because it focuses on the income of the people and the improvement of the living standards of the country's people. In other words, economic development is a process focusing on both qualitative and quantitative growth of the economy, and especially on human beings [1]. The ultimate resource in economic development is people. Human capital develops 
an economy, not financial capital or raw materials [2]. Due to the nature of this multi-dimensional phenomenon, the economic development as measured by the human development index (HDI) can be considered not only a better index compared to the economic growth, but also the cornerstone of the economic growth of a particular country [3-6].

The levels and stages of economic development that countries have faced [2] during the years differ from one to another based on their historical past, political instabilities, wars and conflicts, transition economies, levels of openness and liberalization, and integration processes [7-9]. For countries such as the Western Balkans, establishing the foundations for economic and social development is a fundamental priority not only to ensure sustainable development in terms of the living standards of their citizens, but also to pave the way for their entry into the European Union (hereafter EU). Western Balkan countries-Albania, Bosnia and Herzegovina, Montenegro, North Macedonia, Kosovo, and Serbia-have already realized that reforms such as creating a market economy and increasing the role of the citizen in the society are the guarantee for a new future with peace, stability, prosperity, and freedom. In the last decades, the EU has set the same goals and has supported its activities in the same principles, while recently, it is widely supporting the efforts of the Western Balkan countries by planning to accept them as member states once they meet the conditions for such a thing.

In recent decades, economic development has been a topic of interest for researchers and policymakers across the nations. However, even though it is a widely studied topic, similar types of research for the Western Balkan countries and comparative analyses between the Western Balkans and the EU countries are limited in number $[4,10,11]$. Hence, the main objective of this paper is to empirically test the relationship between economic development, corruption, economic freedom, and urbanization for both the Western Balkan countries and the EU countries to provide a comparative analysis for these two groups. In addition, it aims to derive some quantitative conclusions on the effects that corruption, economic freedom, and urbanization as independent variables have on the dependent variable of the HDI. The last objective of the paper is to provide background information on the HDI, corruption level, economic freedom, and urbanization rates for the two groups of countries so that the paper can have a complete comparative analysis.

The main questions to be answered in this paper are:

(1) How are corruption, economic freedom, and urbanization affecting the economic development of the Western Balkans and the EU countries?

(2) Is the magnitude of this impact greater for the Western Balkans or the EU countries?

To conduct this paper, five of the Western Balkan countries-Albania, Bosnia and Herzegovina, Montenegro, North Macedonia, and Serbia-were taken into consideration. Kosovo was not taken into account, as the data provided for the chosen variables of this paper are either missing or very limited. Even though it is part of the Western Balkans, Croatia joined the EU in 2013, so it will be analyzed under the category of the EU countries-Austria, Belgium, Bulgaria, Croatia, Cyprus, Czech Republic, Denmark, Estonia, Finland, France, Germany, Greece, Hungary, Ireland, Italy, Latvia, Lithuania, Luxembourg, Malta, Netherlands, Poland, Portugal, Romania, Slovakia, Slovenia, Spain, and Sweden. Based on the availability of the data, the period of this paper is 2009-2018, and a multiple linear regression model is used to investigate the relationships among the chosen variables. The model deals with balanced panel data, and the method used is the Panel Estimated Generalized Least Square method.

The first part of the paper provides background information on the human development index, corruption level, economic freedom, and urbanization in general. Additionally, it presents graphical representations of the abovementioned variables for the Western Balkans and the EU countries, putting these countries in front of each other. The second part of the paper includes the literature review and it gives an overview of similar studies conducted in the past, while the third part of the paper corresponds to the presentation of the data and methodology. The fourth part gives the 
empirical results for both groups of countries, followed by the fifth part, which provides the analysis and discussion. The last part of the paper provides the conclusions derived by combining both the theoretical development of the subject and the empirical results, the limitations, and possible recommendations for the future.

\section{Background Information}

\subsection{Human Development Index}

The HDI is a summary measure of average achievement in the main dimensions of human development: a long and healthy life, access to education, and a decent standard of living. The first dimension of the HDI, a long and healthy life, is measured by life expectancy. The second dimension, which stands for being knowledgeable and having access to education, is measured by expected years of schooling of children at school-entry age and mean years of schooling of the adult population. Lastly, the third dimension, which stands for having a decent standard of living, is measured by gross national income per capita adjusted for the price level of the country. The HDI is the geometric mean of normalized indices for each of the three dimensions, and it ranks countries on a scale from 0 to 1 . If a country has a score of $0.8-1.0$, it is considered as a country with very high human development. If the index is between $0.7-0.79$, that country has high human development, while if the index is between $0.55-0.70$, it has medium human development. Countries with a score below 0.55 are categorized as countries with low human development. The HDI was designed to emphasize that people and their skills should be the primary criterion for evaluating the success of a nation, not the economic growth alone [12].

As Figure 1 shows, regarding the HDI for the Western Balkans and the EU countries for the period 2009-2018, on average, the EU countries belong on the tier of countries that have very high human development, as the scores are higher than 0.8, while the Western Balkan countries belong on the tier of countries that have high human development, as the index values vary between 0.74 and 0.78 over the same period. The ratings of Western Balkans are far below those of the EU-27 countries. Among the EU-27, Ireland reached the highest index score of 0.942 in 2018, while in general, Denmark, Germany, the Netherlands, and Sweden have scores higher than 0.9. Among the Western Balkans, the highest index score for the period 2009-2018 was recorded as 0.816 by Montenegro in 2018. At the same time, Montenegro has passed from being a country with high human development to a country with very high human development because, for the period 2013-2018, it reached scores higher than 0.8. Out of 190 countries, which are ranked yearly by the United Nations, according to their HDI scores for 2018, Montenegro is ranked as the 52nd, Serbia as the 63rd, Albania as the 69th, Bosnia and Herzegovina as the 75th, and North Macedonia as the 82nd. Considering the EU-27 countries, out of 190 countries in total, Ireland is ranked as the country with the third highest HDI score for 2018, while Romania and Bulgaria are both ranked as the 52nd [12] (the authors have compiled the average values for each year for both groups of countries, based on the individual data provided for each country).

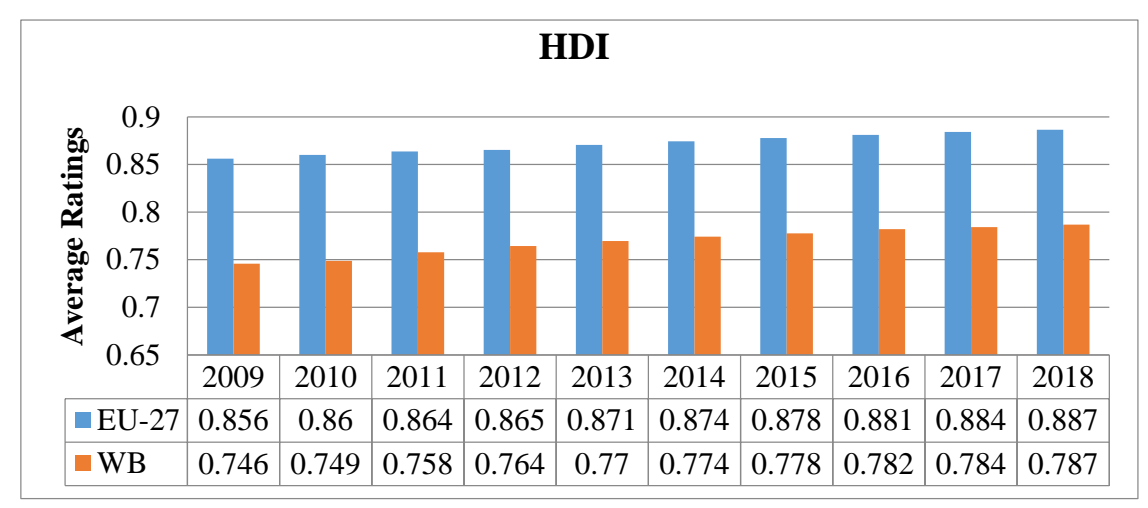

Figure 1. Human development index (HDI): Western Balkans (WB) versus EU-27 (source: authors' own work). 


\subsection{Corruption Levels}

Corruption is an abusive use of rules and procedures that regulate and frame the economic, political, cultural, and social behaviors of each individual. It gives advantages to its actors to the detriment of the majority. It is, therefore, a factor that aggravates social inequalities [13].

Corruption is considered a true enemy to development. It is a ruthless force capable of undermining economies, traditions, society, and nations [14]. Hence, countries and societies must fight to annihilate this ruthless force, or otherwise, people are going to suffer the consequences [15-20]. One of the most known and widely used measurements of corruption is the corruption perception index (CPI) compiled by Transparency International. The CPI ranks 180 countries and territories on a scale of $0-100$ based on their levels of public-sector corruption. A country with an index score of 0 is a highly corrupted country, whereas one with an index score of 100 is very clean [21]. Prior to 2012, the index scored the countries on a scale of $1-10$, so in order not to have a dataset with two different ratings, data for the period before 2012 are multiplied by 10 .

As Figure 2 shows, regarding the CPI for the Western Balkans and the EU countries for the period 2009-2018, on average, the ratings of the Western Balkans are below those of the EU-27 countries. On average, the EU-27 have ratings between 61 and 65 during this period, nearly twice as much as those of the Western Balkans, which have ratings between 35 and 40. In other words, EU-27 countries are less corrupted than the Western Balkan countries. Among the EU-27, Denmark reached the highest index score of 94 in 2011, while in general, Denmark, Finland, and Sweden have scores higher than 85, which make these countries less corrupted than the others. Bulgaria, Croatia, Greece, Italy, and Romania are the ones that, over the years, have faced index scores of 50 or less. Among the Western Balkans, the highest index score for the period 2009-2018 was recorded as 46 by Montenegro in 2017. However, in general, the Western Balkans are perceived as corrupted countries because their scores are lower than 50. Out of 180 countries, which are ranked yearly by Transparency International, according to their latest updates on CPI scores from the least corrupted to the most, Montenegro is ranked as the 66th, Serbia as the 91st, Bosnia and Herzegovina as the 101st, and Albania and North Macedonia are ranked as the 106th. Based on the CPI data, the latter are the most corrupted countries in the region. Denmark, which is part of the EU-27, is ranked as the least corrupted country out of 180 countries [21].

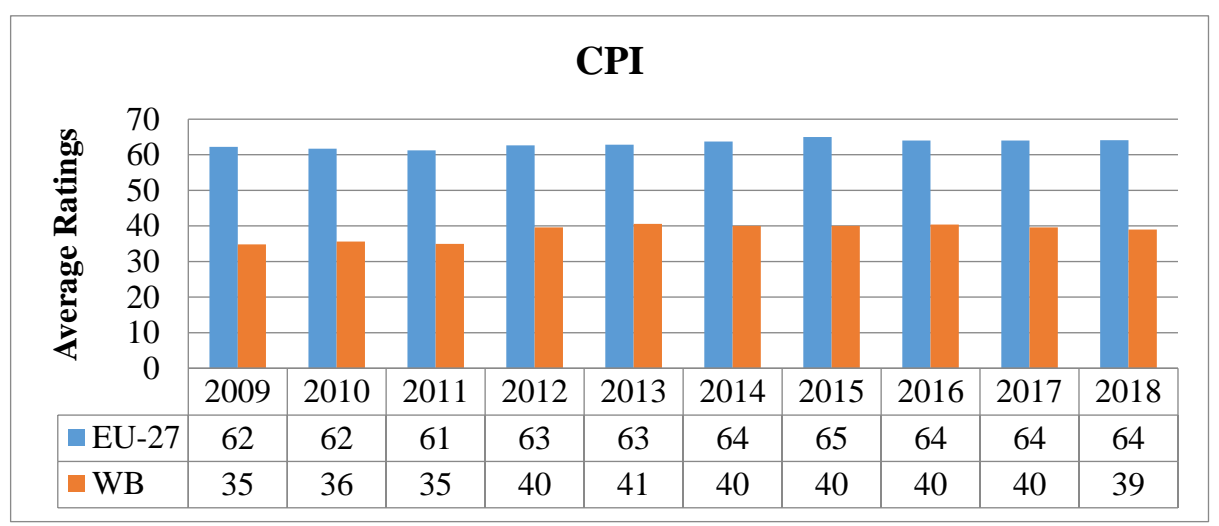

Figure 2. Corruption perception index (CPI): WB versus EU-27 (source: authors' own work).

\subsection{Economic Freedom}

A nation without freedom, such as economic, political, or social freedom, cannot be prosperous. Economic freedom is the fundamental right of every human to control his or her labor and property [22]. The Heritage Foundation measures economic freedom by using an index known as the economic freedom index (EFI), which covers 12 qualitative and quantitative freedoms, from property rights to financial freedom, in 186 countries, and each one of these freedoms is graded on a scale of 0 to 100. A country's overall score is derived by averaging these twelve economic freedoms, with equal 
weight being given to each. A country with an index score of 0 is a country with no economic freedom, whereas one with an index score of 100 is very free in the economic sense.

As Figure 3 shows, regarding the EFI for the Western Balkans and the EU countries for the period 2009-2018, on average, the ratings of the Western Balkans are below those of the EU-27 countries. On average, the EU-27 have index scores around 69 during this period, while the Western Balkans have ratings between 58 and 64 . In other words, the EU-27 countries are freer in the economic sense than the Western Balkan countries. Among the EU-27, Ireland reached the highest index score of 82.2 in 2009, while in general, Denmark, Estonia, and Ireland have scores higher than 75 . The lowest index score for the period 2009-2018 was recorded by Greece in 2016 at 53.2. None of the countries that are part of the EU have index scores of less than 60. Among the Western Balkans, the highest index score for the period 2009-2018 was reached by North Macedonia in 2018 as 71.3, while the lowest index score for the period 2009-2018 was 53.1, reached by Bosnia and Herzegovina in 2009. None of the Western Balkan countries have index scores of less than 50 [22].

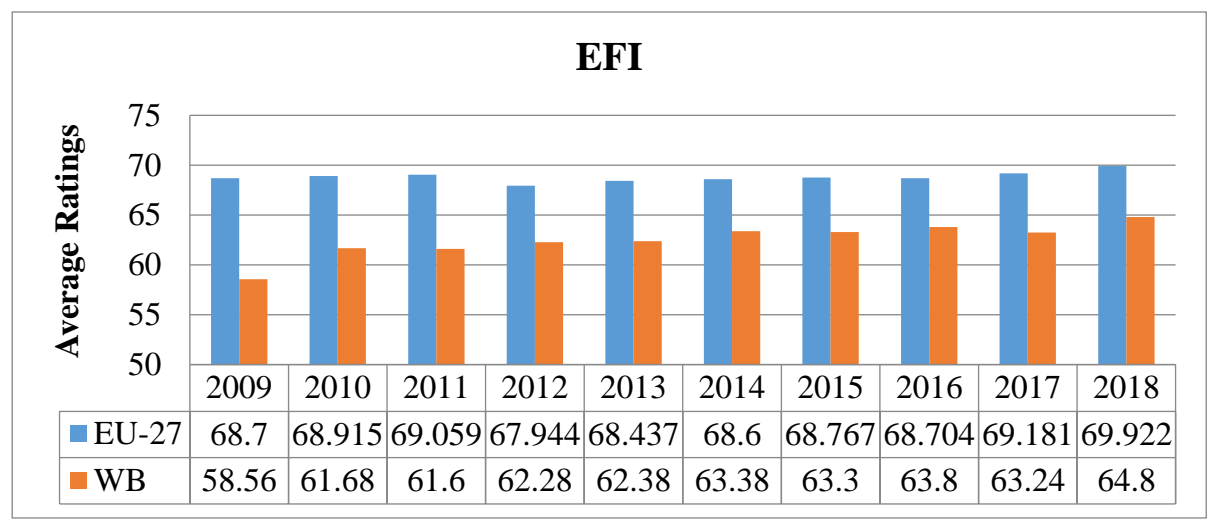

Figure 3. Economic freedom index (EFI): WB versus EU-27 (source: authors' own work).

\subsection{Urbanization}

Urbanization refers to the process by which more and more people leave the countryside to live in cities [23]. A total of $55 \%$ of the world's population lives in urban areas, a proportion that is expected to increase to $68 \%$ by 2050 [24]. The World Bank provides yearly data on the urban population growth of different countries based on the urban ratios provided by the United Nations. As Figure 4 shows, regarding the urban population growth for the Western Balkans and the EU countries, for the period 2009-2018, on average, the ratings of the Western Balkans were below those of the EU-27 countries, except in 2010 and 2011, in which the urban population growth in the Western Balkans surpassed that of the EU-27. On average, for the EU countries, the growth rates vary from $0.2 \%$ to $0.5 \%$, while the Western Balkans mostly have growth rates of $0.2 \%$ and $0.3 \%$. The urban population growth is higher in the EU-27 than in the Western Balkans.

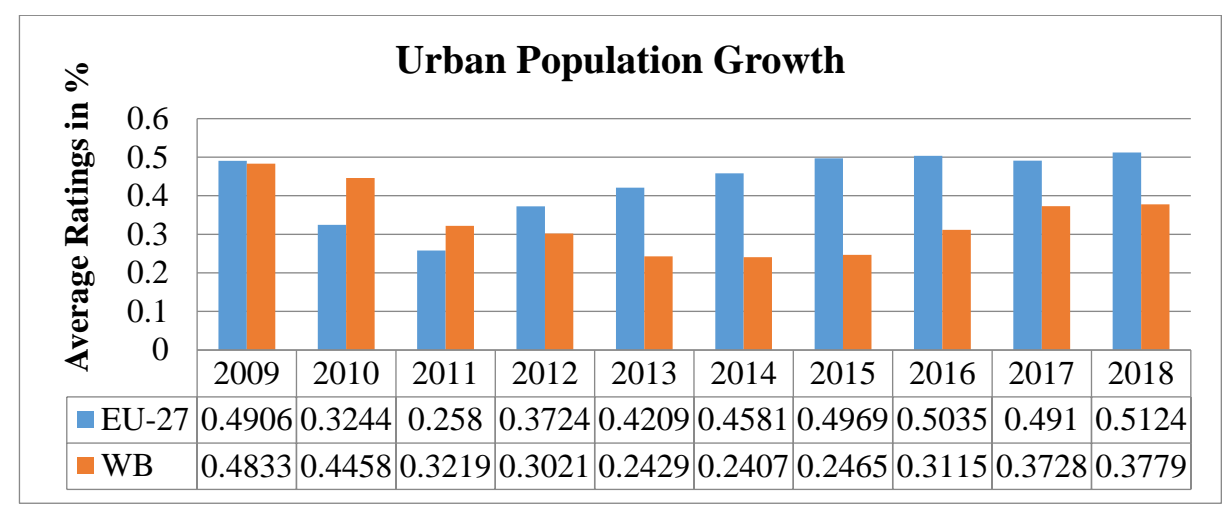

Figure 4. Urban population growth: WB versus EU-27 (source: authors' own work). 
For the period 2009-2018, among the EU-27, Malta recorded the highest percentage increase in the urban population growth at $3.33 \%$ in 2018, while Lithuania recorded the lowest, with a negative growth of $-2.28 \%$ in 2011. Among the Western Balkans, the highest percentage of urban population growth for the period 2009-2018 was reached by Albania in 2012 with 1.84\%, while the lowest was recorded by Bosnia and Herzegovina in 2013 with $-1.05 \%$ [25].

\section{Literature Review}

Economic development is a process focusing on both qualitative and quantitative growth of the economy, centering human beings [1]. Qualitative growth of the economy stands for the positive changes occurring in the human education levels and health standards, while the quantitative growth of the economy refers to the positive changes occurring in the income levels. Due to the nature of this multi-dimensional phenomenon, the economic development as measured by the HDI can be considered a better index compared to the economic growth, which is measured by GDP or GDP per capita, as the dimensions of HDI provide a broader picture of a nation's well-being [6]. Hence, considering the importance of economic development, scholars and researchers have conducted different studies to determine the factors behind different patterns of economic development, factors such as inequalities, poverty, crime rates, corruption, etc. However, based on the main objective of this paper, this literature reviews the relationship between corruption, economic freedom, urbanization, and economic development.

\subsection{Corruption and Development}

Corruption is the degradation of a nation, an oppressor of the social fabric of society, and a significant threat to justice and democracy [26]. The literature provided over the years by the studies of different authors widely accepts the negative impacts of corruption on economic development. According to North (1993), corruption and development have an evolution characterized by an inverse progression considering the need for the existence of complex institutional structures that capture the possible gains from trade and that allow an impersonal exchange in time and space [27].

Corruption is a model of social allocation with strong roots in a society that tends to be stable given that it depends on intrinsic power structures.

Akhter (2004), in his study on 1998 cross-sectional data of 75 countries of all income groups, empirically examines the relation between globalization and human development using a maximum likelihood method [28]. The author claims that higher economic globalization raises the degree of economic freedom and also reduces the level of corruption, which, in effect, enhances human growth. Likewise, Asongu (2012), using a sample of 30 countries together with African development indicators, argues that globalization in terms of trade and finance applied to human development is a strong weapon to combat corruption [29]. However, such a statement does not stand for low-income countries, because in these countries, the emphasis is placed on the economic dimension of international integration.

In addition globalization as a medium of reducing the levels of corruption and enhancing human development, Nielsen and Haugaard (2000) argue that a consolidated democratic system would help in lowering corruption levels, which, in turn, will correspond to higher levels of human development [30]. Using OLS cross-country estimates, the authors claim that greater public services and more government involvement contribute to higher rates of corruption, and it seems possible that corruption not only decreases growth, but it also lowers social spending on education, which is detrimental to human development and productivity. In addition, Akçay (2006) claims that corruption hinders growth, which, in turn, leads to lower GDP per capita. At the same time, corruption lowers spending on education and health, while the decline in the GDP per capita is associated with adverse impacts on living conditions, life expectancy, and human capital accumulation. As a result, the human development level will decline [31]. 
However, the magnitude of the impact of corruption on a nation's welfare differs from one country to another. Similarly to previous studies, Mendonça and Fonseca (2012) argue that corruption hinders growth, as they find strong statistical evidence for a negative impact of corruption on the GDP per capita, an impact that is greater for the developing countries than the developed ones [32]. Hence, improving the CPI will result in a greater positive impact in developing countries as compared to developed countries. Mariyono (2012) suggests that the government should take the needed measures, such as preventive and repressive actions to annihilate corruption, the impact of which is more destructive in developing economies due to dysfunctional institutional factors, while, in general, an increase in the corruption levels causes worse conditions in a nation [33]. Similarly, Letaio (2016) argues that the government agencies in developing countries are often more corrupt and less effective than the ones in developed countries; thus, as a result, the consequences will be higher for developing countries [34]. Hysa and Çela (2019) emphasize the importance of good governance, as they find a positive relationship between good governance indicators and human development [35], supported by Mansi, Hysa, Panait, and Voica (2020), who argue that a good political state influences better economic policies and better harmony in well-being [36]. While Peyton and Belasen (2010) agree on the negative impact of corruption being higher for developing countries [37], Adhikari (2015) declares that countries with higher corruption levels are those that have lower levels of human development; in other terms, developing countries tend to be more corrupt than developed countries [38]. Lastly, Akhbari and Nejati (2019) emphasize that by lowering corruption levels, the environmental quality, which has an impact on human health, gets better, an impact that is higher for developing countries than for developed countries. Taking into consideration the negative impacts of corruption, the authors agree that it is of great importance to find ways to mitigate this impact [39].

Popescu, Duțulescu, and Nișulescu-Ashrafzadeh (2019) argue that corruption activities will vanish only if the causes that generated corruption in the first place disappear [40]. However, considering the EU countries, the authors believe that the problem of corruption is very difficult to control and fully eradicate, irrespective of the efforts made in this regard, as there are political, economic, social, and cultural ties between the EU countries and other countries around the world that are considered as highly corrupted. Still, they conclude that a country with a very low level of corruption must have a strong economy and high living standards. In other words, there is an indirect relationship between corruption and human development. Furthermore, Sarabia, Crecente, del Val, and Giménez (2019), in their analysis of the EU-28 countries for the period 2013-2017, find a high correlation between the HDI and the level of corruption because of the social conflicts that arose among EU citizens as a consequence of the 2008 crisis [41].

Similar studies related to Western Balkan countries are limited in number. Hysa (2011a), in her study on the Western Balkans for the period 2002-2010, argues that the negative relationship between corruption and human development is strong in Serbia, Montenegro, Albania, and Former Yugoslav Republic of Macedonia, weak in Croatia, and insignificant in the case of Bosnia and Herzegovina [4]. Furthermore, in her second study, Hysa (2011b) provides a comparative analysis between Albania and the EU-27 countries for the same period [10]. The findings reveal the negative relationship between corruption and human development for both cases; however, the results suggest that this relationship is much stronger for the Albanian case. Mazllami (2019) provides a comparative analysis of the relationship between the HDI and CPI for Macedonia and Albania for the period 2006-2016 [11]. The empirical results suggest that improving the education levels, health conditions, and standards of living will result in the mitigation of corruption levels in Macedonia, but not in the case of Albania. In other words, the reverse relationship proved to be true only for Macedonia. However, this study has a major limitation, that of the small sample size.

Leaving aside the negative impacts of corruption, the literature review finds evidence of other approaches as well. Heckelman and Powell (2010) argue that corruption has a positive impact on economic growth in those countries that have low levels of economic freedom, as corruption allows entrepreneurs to stay away from inefficient policies and regulations; as a result, these entrepreneurs 
bring new investments into the economy, which will highly likely result in greater economic growth [42]. Moreover, corruption is considered an incentive for the foreign direct investment (FDI), as it helps firms to avoid formal regulations by attracting transactions that, in other terms, are considered inappropriate, while the FDI itself has a positive impact on the economic growth in countries in which the corruption levels are above the threshold level $[43,44]$. Furthermore, countries that are dealing with political instabilities and ineffective institutions may face higher levels of efficiency, as corruption removes conditions that hamper economic development $[45,46]$.

There are certain contexts in which corruption can be beneficial for economic development when the government cannot promote economic activities [47]. Entrepreneurs could use corruption to target bureaucratic support for areas with the greatest growth potential. In this way, an element of competitive bidding could be introduced through which the entrepreneur who offers the biggest bribe would win public resources. Fernández, Gutierrez, and Ramajo (2018) provide evidence in support of the "greasing the wheels" hypothesis by arguing that greater control of corruption means that the number of procedures, number of days, and cost of starting a business have greater negative effects on economic growth [48].

Hoinaru, Buda, Borlea, Văidean, and Achim (2020) argue that corruption may be seen as a way of avoiding the law to attain greater economic benefits, and hence to increase economic development [49]. Even though the authors find evidence for the positive impact of corruption on the economic development of low-income countries, generally speaking, they emphasize the importance of fighting the phenomenon of corruption. Likewise, Jiang and Nie (2014) support the idea that corruption may help private firms to avoid the law, as a result of which their profitability will be higher [50]. Additionally, they mention that there are countries like China where, even though they have highly corrupt governments, their GDP growth rates are increasing tremendously. However, Ahmad, Arfeen, and Ullah (2012), by using panel data on both developing and developed countries, provide evidence that the relationship between corruption and economic growth can be expressed with an inverted U-shaped curve, meaning that a decline in corruption levels will increase the economic growth in an inverted U-shaped way [51].

\subsection{Economic Freedom and Development}

Development is about creating freedom for people and removing obstacles to greater freedom, thus enabling people to choose their destiny [52]. Wallich (1960), in his book "The Cost of Freedom", reflects the traditional wisdom of that time, which emphasizes the importance of government interventions, such as increasing regulations and taxation as a means of lowering unemployment and having a fair distribution of income [53]. The author considers the loss of economic and personal freedom as something worth achieving as policy goals. However, his student, Grubel (1998), argues that economic freedom is not related to economic costs; instead, it provides economic benefits [54]. Based on his analysis, he argues that higher economic freedom is associated with lower unemployment levels, higher levels of human development, and higher performance of all the criteria of human well-being.

Madan (2002), in her study of 152 countries of different categories of income, argues that the greater the economic freedom of a country, the greater the quality of people's lives in that country; however, her empirical results suggest that as economic freedom increases more quickly, the human development suffers [55]. Still, the insignificance of such a result makes it possible to conclude that what matters for socioeconomic development is the level of freedom and not the pace of change. Additionally, the author argues that at the beginning of the process of becoming free, countries face greater income inequalities, and after some time, they start to benefit from economic freedom. Moreover, Claessen and Bellavitis (n.d), in their study of 66 developing countries for the period 1998-2007, observe a change in the sign of the relationship between human development and economic freedom for middle-income countries when performing the robustness check [56]. As a result, they provide no general conclusions on the relationship between human development and economic freedom, other than that it tends to be a positive one. 
Likewise, Akhter (2004) argues on behalf of the positive relationship between economic freedom and economic development [28]. The author contends that a higher degree of economic freedom implies greater incentives for business transactions in combination with the legal security of the property. Moreover, a higher degree of economic freedom contributes to higher standards of living, and as a result, the demand for goods and services, both domestically generated and imported, would be higher. Vondrová and Fifeková (2016) state that the fundamental criteria of economic freedom are the political and civil rights that each individual enjoys, and as a result, the quality of a person's life is greatly determined by these criteria [57]. Using a nonparametric approach for the European countries, the authors contend that countries can enhance their economic performance by increasing the level of their economic freedom. The authors suggest that improvements in property rights are a potential source of economic development for all countries. Still, Chang (2007) argues that it is important to clarify what is considered a "good" property rights system in order to be able to identify the exact conditions under which particular institutions help economic development [58]. However, not all countries benefit the same from economic freedom; countries with the least human development benefit more from improvements in economic freedom [59]. Using the conditional quantile regression method for 88 countries, the author argues that at a lower level of HDI distribution, economic freedom appears to have a pronounced influence, and then settles down from the middle to upper quantiles. Similarly, Gehring (2013) suggests that developing countries tend to benefit more from economic freedom than developed countries in terms of higher well-being due to the adaption effects in developed countries; thus, economic freedom tends to have a larger impact on the well-being in developing countries than in developed ones [60]. The author suggests that to increase economic freedom in developing countries, it is important to reduce unnecessary regulations. Furthermore, Corbi (2007) declares that, in particular, countries with low levels of income are the ones that grow rapidly when their policies encourage economic freedom, which is of high importance for achieving prosperity [61].

Contrary to the previous studies, which have widely used the HDI as a measure of economic development and human well-being, Graafland (2019) examines the relationship between economic freedom and well-being by using 11 dimensions of the Better Life Index provided by the Organization for Economic Co-operation and Development (OECD) [62]. The author argues that this relationship is moderated by long-term orientation. He finds a positive relationship for most of the well-being indicators and a negative relationship between leisure (work-life balance) and economic freedom. Still, the results suggest that long-term orientation diminishes the negative relationship between these two variables. The author concludes that economic freedom is particularly related to well-being in a cultural environment where people exhibit virtues that enable them to engage in future-oriented behaviors, and this long-term orientation helps them keep a balance between their work and their life.

\subsection{Urbanization and Development}

Urbanization referrers to the process by which more and more people leave the countryside to live in cities [23]. Over the years, researchers have conducted different studies on the impact of urbanization on economic development. As the results of the various studies are contradictory, the debate remains open about whether urbanization has a positive or negative impact on the development of a country.

Njoh (2003) studies the relationship between urbanization rates and the HDI in the countries having a Stabilization and Association Agreement (SAA), basing his hypothesis on the modernization theories, which see urbanization as part of a natural process that provides positive outcomes for societal and national development [63]. Forming two different groups of countries, in which one has higher urbanization rates than the other, the author finds out that the one with higher urbanization rates tends to perform better in terms of human development, indicating a positive relationship between the chosen variables. Similarly, Akçay (2006) sees urbanization as a natural part of the development process, and by taking into consideration both developing and developed countries, he argues that residents in urban areas not only have more opportunities for greater incomes, but also greater access to education and services such as healthcare and other social services, meaning that in urban areas, 
there is a higher human development than in rural areas, as urbanization tends to increase human development [31]. Duranton (2014) argues that for both developed and developing countries, there is a positive impact of the city's size on the outcomes of the productivity (income levels), an impact that is small for both cases, but higher for the developing countries [64]. Additionally, Bertinelli and Zou (2008) emphasize the role played by cities in stimulating human capital accumulation [65]. The emergence of a greater number of urban dwellers appears to support the development of human capital within a delay of five years, even after the authors controlled for the general levels of development: GDP per capita, life expectancy, and fertility. The authors argue that cities serve as an ether, where barriers to the flow of information and knowledge diminish and closeness among people supports connections that could be the core of human capital spillovers. In exchange, opportunities to fund education are increased, leading to higher rates of education and bettering people' lives. Odugbesan and Rjoub (2020) conducted a study for MINT countries using data from 1993 to 2017 and employing the autoregressive distributed lag (ARDL) Bounds test approach. The study was focused on the relationship between economic growth, $\mathrm{CO}_{2}$ emissions, urbanization, and energy consumption. The authors proposed a solution for sustainable urbanization in MINT countries by ensuring the reduction in the urbanization level through the public authorities without compromising the economic growth. So, the aim is green and intelligent urbanization [66].

Likewise, the empirical results of the study that Huang and Jiang (2017) conducted on Inner Mongolia for 2000 and 2010 suggest that higher urbanization rates are associated with higher values of the HDI, even after controlling for the possible effects of GDP [67]. The authors emphasize that both GDP per capita and HDI scores are higher in urban districts than in rural counties of the same prefecture, supporting the claim that cities perform better in terms of economic and social development as compared to their surrounding rural areas. Mayer-Foulkes (2012) declares that urbanization is one of the most significant determinants of the HDI, as it has a positive significant impact on each of the HDI's components; however, it appears that urbanization has a higher impact on middle-income countries, which can make it a development tool [68]. Authors argue that as urbanization tends to improve human development, it is important to promote balanced urbanization. To obtain the maximum benefits of urbanization, sustainable urbanization that involves sufficient delivery of basic services, such as infrastructure, electricity and water, medical facilities, etc., is needed to ensure that the process of urbanization is consistent with the principles of sustainable development $[69,70]$.

Contrary to the previous findings, Moore, Gould, and Keary (2003) argue that even though cities offer greater opportunities for better education, jobs, and healthcare, they put human health at risk when there is a fast and unexpected urban growth [71]. Such a development within the developing world is often tied to deprivation of the basic needs, environmental devastation, demand surpassing service supply at a great scale, air pollution, contaminated drinking water, inadequate sanitation, and substandard housing, all of which tend to lead to different diseases, putting human health at serious risk. Likewise, Eckert and Kohler (2014) emphasize that in developing countries, population density is high while sanitation conditions are not at their best levels; as a result, urbanization is associated with various health conditions, some of which may be improved, while some others may get worse [72]. Szabo (2016) argues that rapid urbanization has a negative impact on food security; the less secure the food provided to the people of a country is, the more exposed are these people to health risks, a phenomenon that is more common in countries with the lowest values of human development [73]. Similarly, Dociu and Dunarintu (2012) argue that developing new urban areas without following appropriate steps to develop sustainable areas would have a negative effect on the environment with serious consequences for human health. Additionally, the authors emphasize that the impact of urbanization is greater for less developed states [74].

Still, Martínez-Zarzoso and Maruotti (2011), in their study on developing countries, argue that once urbanization has reached a certain level, its impact on $\mathrm{CO}_{2}$ emissions will turn out to be negative, leading to a reduction in environmental harm [75]. Moreover, the authors highlight that the benefits associated with urbanization surpass the disadvantages. For developing countries to minimize the 
costs associated with urbanization and to be able to gain from the benefits that it brings, it is important to create adequate urban planning policies, aiming to achieve urban sustainability [76].

\subsection{Hypotheses}

Based on the literature review and the objectives of this paper, the hypotheses that are going to be tested are as follows:

Hypothesis 1. Corruption has a significant negative impact on the economic development of both the Western Balkan countries and the EU-27, but the impact is more destructive for the Western Balkans.

Hypothesis 2. Economic freedom has a significant positive impact on the economic development of both the Western Balkan countries and the EU-27, but the Western Balkans benefit more from economic freedom.

Hypothesis 3. Urbanization has a significant positive impact on the economic development of both the Western Balkan countries and the EU-27, but the Western Balkans benefit more from urbanization.

\section{Data and Methodology}

\subsection{Data}

The main objective of this paper is to empirically test the relationship between economic development, corruption, economic freedom, and urbanization for both the Western Balkan countries and the EU countries to provide a comparative analysis for these two groups. To test these relations, two balanced sets of panel data were created and used: one for five of the Western Balkan countries-Albania, Bosnia and Herzegovina, North Macedonia, Montenegro, and Serbia, leaving Kosovo aside because of the very limited availability of the data-and the other one for EU countries-Austria, Belgium, Bulgaria, Croatia, Cyprus, Czech Republic, Denmark, Estonia, Finland, France, Germany, Greece, Hungary, Ireland, Italy, Latvia, Lithuania, Luxembourg, Malta, the Netherlands, Poland, Portugal, Romania, Slovakia, Slovenia, Spain, and Sweden. The samples of this paper consist of secondary data collected from different reliable sources, such as the Heritage Foundation, Transparency International, the United Nations, and World Bank Indicators. There are 50 observations for the Western Balkan countries and 270 observations in total for the EU countries. Based on the availability of the data, this paper deals with annual data for the period 2009-2018. The following Table 1, describes the data chosen for the empirical analysis of this paper.

Table 1. Description of data.

\begin{tabular}{cccc}
\hline Data & Type & Unit of Measurement & Source \\
\hline HDI & Quantitative Data (Interval) & Scale 0-1 & United Nations \\
CPI & Quantitative Data (Interval) & Scale 0-100 & Transparency International \\
EFI & Quantitative Data (Interval) & Scale 0-100 & Heritage Foundation \\
URgrw & Quantitative Data (Ratio) & Annual \% & World Bank Indicators \\
\hline
\end{tabular}

The HDI is considered a better index for measuring the economic development of a country as compared to the economic growth measured by the GDP because the HDI measures both the qualitative and quantitative growth of the economy $[1,3,6,77]$. Designed to emphasize that people and their skills should be the primary criteria for evaluating the success of a nation and ranking countries on a scale of 0-1 (a score of 0.8-1.0 indicates very high human development, while a score of 0.7-0.79 indicates high human development; a score of 0.55-0.70 indicates medium human development, while a score below 0.55 indicates low human development), the HDI measures the average achievement in three main dimensions of human development: a long and healthy life (measured by the life expectancy 
index), access to education (measured by the education attainment index), and decent standards of living (measured by the adjusted income index) [12].

The CPI, created by Transparency International, is used widely in different studies as a proxy for corruption levels $[11,28,30,33,40,78]$. Based on the levels of public-sector corruption, information on which is gathered through a combination of 13 surveys provided by reputable institutions, the CPI ranks countries and territories on a scale of $0-100$, with 0 indicating a highly corrupt country, whereas a country with an index score of 100 is very clean [21] (prior to 2012, the index used to score the countries was on a scale of $1-10$, but in order not to have a dataset with two different ratings, data for the period before 2012 are multiplied by 10; Lopez (2019) proceeded in the same way).

The EFI, created by the Heritage Foundation, is used in various studies as a proxy for economic freedom $[28,31,54-56]$. The EFI is derived by averaging 12 qualitative and quantitative freedoms (judicial effectiveness, property rights, and government integrity fall under the category of rule of law; fiscal health, government spending, and tax burden fall under the category of government size; monetary freedom, business freedom, and labor freedom belong to the category of regulatory efficiency, while financial freedom, trade freedom, and investment freedom are part of the category of open markets; in total, there are four broad categories and 12 freedoms (Heritage Foundation, 2020), with equal weight being given to each, grading these freedoms on a scale of 0 to 100 . A country with an index score of 0 is a country with no economic freedom, whereas one with an index score of 100 is very free in the economic sense [22].

Urban population refers to residents of urban areas, while the urban population growth stands for the increase in the number of people who live in urban areas [79]. Urban population growth (URgrw) is used as a proxy for urbanization, based on one of many variables chosen by Sabyasachi (2019) in his study on the relation of urbanization and human development [70]. The World Bank provides the yearly percentage data on urban population growth of different countries based on the urban ratios provided by the United Nations [25].

\subsection{Methodology}

To empirically test the relationship between economic development (HDI), corruption (CPI), economic freedom (EFI), and urbanization (URgrw) for both the Western Balkan countries and the EU countries, a multiple regression analysis was used as an analytical tool to identify regression equations and to derive conclusions on the effects that the chosen independent variables have on the dependent variable. The CPI, EFI, and URgrw are the independent variables, while the HDI is the dependent variable, as specified in Table 2. Prior to running the regression, some tests and correlation matrices were conducted to avoid any biases in the results, such as the unit root test to check for the stationarity of data, multicollinearity checking via the correlation matrix, and zero conditional mean checking via the correlation matrix of the residuals and independent variables.

Table 2. Variables and multiple regression equation.

\begin{tabular}{cc}
\hline & $\mathrm{HDI}_{\mathbf{i}}=\alpha_{\mathbf{0}}+\alpha_{\mathbf{1}} \mathrm{CPI}_{\mathbf{i}}+\alpha_{\mathbf{2}} \mathrm{EFI}_{\mathbf{i}}+\alpha_{\mathbf{3}} \mathrm{URgrw}_{\mathbf{i}}+\mathrm{e}_{\mathbf{i}}$ \\
\hline $\mathrm{HDI}_{\mathrm{i}}$ & The dependent variable, proxy for economic development \\
$\mathrm{CPI}_{\mathrm{i}}$ & Independent variable, proxy for corruption level \\
$\mathrm{EFI}_{\mathrm{i}}$ & Independent variable, proxy for economic freedom \\
$\mathrm{URgrw}_{\mathrm{i}}$ & Independent variable, proxy for urbanization \\
$\alpha_{0}$ & Constant, intercept of the equation \\
$\alpha_{1}, \alpha_{2}, \alpha_{3}$ & Parameters of the equation \\
$e_{i}$ & Error term \\
$\mathrm{i}$ & "i " is the individual dimension of the panel \\
\hline & Source: Authors' own work.
\end{tabular}


The multiple regression equation can be presented as follows:

$$
\mathrm{HDI}_{\mathrm{i}}=\alpha_{0}+\alpha_{1} \mathrm{CPI}_{\mathrm{i}}+\alpha_{2} \mathrm{EFI}_{\mathrm{i}}+\alpha_{3} \mathrm{URgrw}_{\mathrm{i}}+\mathrm{e}_{\mathrm{i}}
$$

The basis of the regression model of this paper is from Akçay (2006), who sees human development [31] as a function of corruption, economic freedom, urbanization, and democracy:

$$
\mathrm{HDI}=\mathrm{f}(\mathrm{CPI}, \mathrm{EFI}, \mathrm{UR}, \mathrm{DEM})
$$

For estimating the abovementioned regression equation for both groups of countries (the Western Balkans and the EU countries), there are two models for panel data: the Fixed Effect model and Random Effect model, which fall under the Panel Generalized Least Square method. Mariyono (2012) and Claessen and Bellavitis (n.d) use the Panel Generalized Least Square method as a better way to estimate econometric models for panel data and also to deal with cases where there may be problems with the error term in the OLS estimates [33,56].

The Hausman test, which assumes that the Random Effect model is more appropriate than the Fixed Effect model, was used to see whether such an assumption stands or not and to choose the most appropriate model for this paper. White cross-section standard errors and covariance were used to eliminate any opportunity of facing heteroskedasticity and serial correlation. Lastly, the t-test shows if the CPI, EFI, and URgrw have significant individual impacts on the HDI, while the F-test shows the overall significance of the model.

\section{Empirical Results}

\subsection{Descriptive Statistics}

Referring Table 3 regarding the HDI, the Western Balkan countries have an average of 0.77, while the EU-27 countries have an average of 0.87 for the period 2009-2018. The numbers indicate that the Western Balkans belong on the tier of the countries, which have a high human development, while the EU-27 belong on the tier of the countries that have very high human development. The highest index score for the Western Balkans is 0.816, recorded by Montenegro in 2018, whereas the highest index score for the EU-27 countries is 0.942 , reached by Ireland in 2018. The minimum index score for the Western Balkans is the one recorded by Bosnia and Herzegovina in 2010 as 0.714 , while among the EU-27 countries, the minimum score of 0.774 was recorded by Bulgaria in 2009. Standard deviations for both cases are very low and nearly the same, indicating that the index scores for both cases are not very spread out.

Table 3. Descriptive statistics.

\begin{tabular}{ccccccccc}
\hline & \multicolumn{2}{c}{ HDI } & \multicolumn{2}{c}{ CPI } & \multicolumn{2}{c}{ EFI } & \multicolumn{2}{c}{ URgrw } \\
\hline & WB & EU-27 & WB & EU-27 & WB & EU-27 & WB & EU-27 \\
\hline Mean & 0.7691 & 0.8719 & 38.457 & 63.143 & 62.502 & 68.822 & 0.3345 & 0.43282 \\
Median & 0.7700 & 0.8730 & 39.000 & 61.000 & 62.550 & 68.900 & 0.2331 & 0.4627 \\
Maximum & 0.8160 & 0.9420 & 46.000 & 94.039 & 71.300 & 82.200 & 1.8483 & 3.3344 \\
Minimum & 0.7140 & 0.7740 & 30.000 & 33.289 & 53.100 & 53.200 & -1.0549 & -2.2824 \\
Std. Dev & 0.0265 & 0.0388 & 4.2694 & 16.065 & 4.1483 & 5.6379 & 0.7757 & 0.86405 \\
Obs & 50 & 270 & 50 & 270 & 50 & 270 & 50 & 270 \\
\hline \multicolumn{9}{c}{ Source: Authors' own work. }
\end{tabular}

Considering the CPI, the Western Balkan countries have an average of 38.45, while the EU-27 countries have an average of 63.14 for the period 2009-2018. The mean scores show that Western Balkan countries have higher corruption levels as compared to the EU-27 countries. The highest index score for the Western Balkans is 46, recorded by Montenegro in 2017, whereas the highest index score for the EU-27 countries is 94, reached by Denmark in 2011. The minimum index score for the Western 
Balkans is the one recorded by Bosnia and Herzegovina in 2009 as 30, while among the EU-27 countries, the minimum score of 33.28 was recorded by Bulgaria in 2011. The EU-27 has a very high standard deviation as compared to the Western Balkans, indicating that the data are more spread out from the mean and that the Western Balkans have more consistent index scores.

Taking into account the EFI, the Western Balkan countries have an average of 62.50, while the EU-27 countries have an average of 68.82 for the period 2009-2018. The mean scores show that the EU-27 countries are freer in the economic sense as compared to the Western Balkans. The highest index score for the Western Balkans is 71.3, recorded by North Macedonia in 2018, whereas the highest index score for the EU-27 countries is 82.2, reached by Ireland in 2009. The minimum index score for the Western Balkans is the one recorded by Bosnia and Herzegovina in 2009 as 53.1, while among the EU-27 countries, the minimum score of 53.2 was recorded by Greece in 2016. The EU-27 has a standard deviation higher than that of the Western Balkan countries, indicating that the data are more spread out from the mean and that the Western Balkans have more consistent index scores.

Regarding the urbanization growth rates, the Western Balkan countries have an average of 0.33 , while the EU-27 countries have an average of 0.43 for the period 2009-2018. Among the Western Balkans, the highest percentage of urban population growth was reached by Albania in 2012 with $1.84 \%$, while among the EU-27, Malta recorded the highest percentage increase in the urban population growth with $3.33 \%$ in 2018 . The lowest percentage of urban population growth for the Western Balkans is the one recorded by Bosnia and Herzegovina, with a negative growth of $-1.05 \%$ in 2013 , whereas among the EU-27 countries, the lowest percentage of urban population growth was recorded by Lithuania, with a negative growth of $-2.28 \%$ in 2011. Standard deviations for both cases are very low and nearly the same, indicating that index scores for both cases are not very spread out.

\subsection{Hausman Test}

To determine whether a Fixed Effect model or a Random Effect model was more appropriate for the regression analysis of this paper, the Hausman test was run for both groups of countries-the Western Balkans and the EU countries. The hypotheses of this test are as follows:

Hypothesis 4 (null hypothesis). The Random Effect model is more appropriate.

Hypothesis 4 (alternative hypothesis). The Fixed Effect model is more appropriate.

The probability of the Hausman test in both cases is 1 , indicating that at any level of significance, $10 \%, 5 \%$, or $1 \%$, the null hypothesis cannot be rejected. As a result, confirming from Table 4 , the Random Effect model for both the Western Balkan countries and the EU countries was used to find the regression equations and to derive conclusions.

Table 4. Hausman Test: Fixed Effect (FE) or Random Effect (RE).

\begin{tabular}{cccc}
\hline WB Test Summary & $\mathrm{Chi}^{2}$ Statistic & $\mathrm{Chi}^{2}$ d.f. & Probability \\
\hline Period Random & 0.000000 & 3 & 1.0000 \\
\hline EU-27 Test Summary & $\mathrm{Chi}^{2}$ Statistic & $\mathrm{Chi}^{2}$ d.f. & Probability \\
\hline Period Random & 0.000000 & 3 & 1.0000 \\
\hline \multicolumn{4}{c}{ Source: Authors' own work. }
\end{tabular}

\subsection{Other Tests}

Prior to running the regression equations, it is important to check for the stationarity of data, multicollinearity problems, and the correlation of the independent variables and residuals, which are key conditions for unbiased regression parameters. The unit root test was used to check whether each one of the chosen variables, whether independent or dependent, has a unit root or not; in other words, 
if these variables are stationary or not. For both the Western Balkan countries and the EU countries, the results of this test suggest that each of the chosen variables is stationary in levels. Additionally, multicollinearity is not a problem, as the correlation between the independent variables is less than 0.8 , which is considered as a threshold level. Furthermore, the zero conditional mean assumption that stands for 0 correlation between independent variables and residuals, as well as residuals having a mean of 0 , is not violated, as for both the Western Balkans countries and the EU countries, the mean of the residuals and the correlation of the independent variables and residuals are 0 .

\subsection{Random Effect Model for the Western Balkans}

Using the Random Effect model for the Western Balkan countries, it turns out that the impact of the CPI, EFI, and URgrw on the HDI is highly significant at the $5 \%$ and $10 \%$ level of significance, since their respective $p$-values are less than the levels of significance, while at $1 \%$, the CPI and URgrw are highly significant, whereas the EFI is just significant. Thus, according to the results in Table 5, the $t$-statistics suggest that each one of the independent variables has a statistically significant impact on the dependent variable for the Western Balkans. The probability (F-statistic) is less than any level of significance $(1 \%, 5 \%$, and $10 \%)$, meaning that the overall model is statistically significant. The adjusted $R^{2}$ suggests that for the case of the Western Balkan countries, $40.7 \%$ of the variation in the HDI is explained by this model.

Table 5. Random Effect model for the Western Balkans.

\begin{tabular}{ccccc}
\hline \multicolumn{5}{c}{ Dependent Variable: HDI } \\
\hline \multicolumn{5}{c}{ Method: Panel EGLS } \\
\hline \multicolumn{5}{c}{ Sample: 2009 2018 } \\
\hline \multicolumn{5}{c}{ Periods included: 10 } \\
\hline \multicolumn{5}{c}{ Cross-sections included: $\mathbf{5}$} \\
\hline Total panel (balanced) observations: 50 \\
\hline Coefficient & Std. Error & t-Statistic & Prob. \\
\hline CPI & 0.004513 & 0.000683 & 6.611624 & 0.0000 \\
EFI & 0.002351 & 0.000884 & 2.658805 & 0.0108 \\
URgrw & 0.024286 & 0.004465 & 5.439211 & 0.0000 \\
C & 0.734418 & 0.066496 & 11.04461 & 0.0000 \\
R-squared & 0.443616 & & \\
Adjusted R-squared & 0.407330 & & \\
F-statistic & 12.22555 & & \\
Prob (F-statistic) & 0.000005 & & \\
\hline \multicolumn{5}{c}{ Source: Authors' own work. }
\end{tabular}

\subsection{Random Effect Model for the EU Countries}

Using the Random Effect model for the EU countries, it turns out that the impact of the CPI, EFI, and URgrw on the HDI is highly significant at the $1 \%, 5 \%$, and $10 \%$ level of significance, since their respective $p$-values are less than the levels of significance. Similarly to the Western Balkan countries, the t-statistics suggest that each one of the independent variables has a statistically significant impact on the dependent variable for the EU countries. The probability (F-statistic) is less than any level of significance $(1 \%, 5 \%$, and $10 \%)$, meaning that the overall model is statistically significant. The adjusted $\mathrm{R}^{2}$ suggests that for the case of the EU countries, $70.6 \%$ of the variation in the HDI is explained by this model, as in Table 6. 
Table 6. Random Effect model for the EU countries.

\begin{tabular}{ccccc}
\hline \multicolumn{5}{c}{ Dependent Variable: HDI } \\
\hline \multicolumn{5}{c}{ Method: Panel EGLS } \\
\hline \multicolumn{5}{c}{ Sample: 2009 2018 } \\
\hline \multicolumn{5}{c}{ Periods included: 10 } \\
\hline \multicolumn{5}{c}{ Cross-sections included: 27 } \\
\hline \multicolumn{5}{c}{ Total panel (balanced) observations: 270 } \\
\hline Variable & Coefficient & Std. Error & t-Statistic & Prob. \\
CPI & 0.001868 & $6.78 \times 10^{-5}$ & 27.52807 & 0.0000 \\
EFI & 0.000335 & 0.000108 & 3.087124 & 0.0022 \\
URgrw & 0.007086 & 0.001122 & 6.312794 & 0.0000 \\
C & 0.774000 & 0.004868 & 159.0025 & 0.0000 \\
R-squared & 0.709491 & & \\
Adjusted R-squared & 0.706215 & & \\
F-statistic & 216.5452 & & \\
Prob(F-statistic) & 0.000000 & & \\
\hline
\end{tabular}

Source: Authors' own work.

\section{Analysis and Discussion}

Based on the empirical results of the Random Effect models used for both the Western Balkan countries and the EU countries, the regression equations are as follows:

$$
\begin{gathered}
\mathrm{WB} \rightarrow \mathrm{HDI}_{\mathrm{i}}=0.734+0.004 \mathrm{CPI}_{\mathrm{i}}+0.002 \mathrm{EFI}_{\mathrm{i}}+0.024 \mathrm{URgrw}_{\mathrm{i}}+\mathrm{e}_{\mathrm{i}} \\
(0.0664)(0.0006)(0.0008)(0.0044) \\
\mathrm{R}^{2}=0.443616 \text { Adj } \mathrm{R}^{2}=0.407330 \mathrm{~F}-\mathrm{stat}=12.22555 \mathrm{Prob}(\mathrm{F}-\mathrm{stat})=0.0000 \\
\mathrm{EU}-27 \rightarrow \mathrm{HDI}_{\mathrm{i}}=0.774+0.001 \mathrm{CPI}_{\mathrm{i}}+0.0003 \mathrm{EFI}_{\mathrm{i}}+0.007 \mathrm{URgrw}_{\mathrm{i}}+\mathrm{e}_{\mathrm{i}} \\
(0.0048)\left(6.78 \times 10^{-5}\right)(0.0001)(0.0011) \\
\left.\mathrm{R}^{2}=0.709491 \text { Adj } \mathrm{R}^{2}=0.706215 \mathrm{~F} \text {-stat }=216.5452 \text { Prob(F-stat }\right)=0.0000
\end{gathered}
$$

Both regression equations have the expected signs for each parameter of the independent variables.

Hypothesis 1. Corruption has a significant negative impact on the economic development of both the Western Balkan countries and the EU-27, but the impact is more destructive for the Western Balkans.

The parameter of the CPI has a positive sign in both cases, indicating that an increase in the CPI scores, ceteris paribus, tends to lead to an increase in the HDI scores. Since higher CPI scores mean a lower level of corruption, the empirical results suggest that higher levels of corruption are associated with lower levels of the HDI. Authors like Hysa (2011a), Mariyono (2012), and Lopez (2019) have provided the same interpretation for the association between the CPI and HDI [4,33,78]. The parameters of the CPI are quite small for both cases; however, the CPI is highly significant at all levels of significance. A one-point increase in the CPI, ceteris paribus, tends to increase the HDI by 0.004 points for the Western Balkan countries and 0.001 points for the EU countries.

The impact of the CPI on the HDI is greater in the Western Balkans than in the EU countries. Hence, the first hypothesis can be accepted, concluding that corruption has a significant negative impact on the economic development of the Western Balkan countries and the EU countries, an impact that is more destructive for the Western Balkans.

The empirical results are in accordance with the literature review. Once again, this empirical analysis emphasizes the indirect relationship between corruption and economic development, 
a relationship that has been widely accepted over the years $[4,11,28,30,31,33,40,41]$. The impact appears to be higher for the Western Balkan countries, similarly to Mendonça and Fonseca (2012), who argue that improving the CPI will result in a greater positive impact in developing countries as compared to developed countries [32]. Likewise, Letaio (2016) and Mariyono (2012) argue that due to dysfunctional institutional factors and inefficient government agencies, the impact of corruption on developing countries is more destructive $[33,34]$. Corruption hinders growth and lowers spending on education and health, which is detrimental to human development [30,31] (it leads to a weak economy with low life expectancy, human capital accumulation, and living standards [31,40]).

Hypothesis 2. Economic freedom has a significant positive impact on the economic development of both the Western Balkan countries and the EU-27, but the Western Balkans benefit more from economic freedom.

The parameter of the EFI has a positive sign in both cases, indicating that an increase in the EFI scores, ceteris paribus, tends to lead to an increase in the HDI scores; hence, higher levels of economic freedom are associated with higher levels of the HDI. The parameters of the EFI are quite small for both cases; however, the EFI is significant at all levels of significance. A one-point increase in the EFI, ceteris paribus, tends to increase the HDI by 0.002 points for the Western Balkan countries and 0.0003 points for the EU countries. The impact of the EFI on the HDI is greater in the Western Balkan countries than in the EU countries. Thus, the second hypothesis can be accepted, concluding that economic freedom has a significant positive impact on the economic development of both the Western Balkan countries and the EU countries, but the Western Balkans benefit more from economic freedom.

The empirical results regarding the direct relationship between economic freedom and economic development are in accordance with past similar studies [28,54-56,59,62]. The impact of economic freedom on economic development appears to be higher in the Western Balkan countries, similarly to Naanwaab (2018), who argues that not all countries have the same benefit from economic freedom, but countries with the least human development benefit more from improvements in the economic freedom [59]. In comparison to the EU countries, the Western Balkans have lower levels of human development; thus, they tend to benefit more from economic freedom. Additionally, such a result is supported by Gehring (2013), who suggests that economic freedom tends to have a greater positive impact on the well-being in developing countries than in developed ones [60]. Higher economic freedom is associated with lower unemployment levels, greater incentives for business transactions in combination with the legal security of property, which is considered a potential source of economic development, higher standards of living, and higher performance of all of the criteria of human well-being and the quality of people's lives. As a result, the demand for goods and services, both domestically generated and imported, would be higher $[28,54,55,57]$.

Hypothesis 3. Urbanization has a significant positive impact on the economic development of both the Western Balkan countries and the EU-27, but the Western Balkans benefit more from urbanization.

The parameter of URgrw has a positive sign in both cases, indicating that an increase in the urban population growth, ceteris paribus, tends to lead to an increase in the HDI scores; hence, higher urbanization levels are associated with higher levels of the HDI. The parameters of URgrw are small for both cases; however, URgrw is highly significant at all levels of significance. A $1 \%$ increase in URgrw, ceteris paribus, tends to increase the HDI by 0.024 points for the Western Balkan countries and 0.007 points for the EU countries. Hence, the third hypothesis can be accepted, concluding that urbanization has a significant positive impact on the economic development of both the Western Balkan countries and the EU countries, but the Western Balkans benefit more from urbanization.

Even though the literature provides contradictory outcomes in terms of the relationship between urbanization and economic development, the empirical results of this paper support the group of studies that have found a positive association between them $[31,63,65,67,75]$. The impact of urbanization on economic development appears to be higher in the Western Balkan countries, similarly to Mayer-Foulkes 
(2012), who declares that urbanization is one of the most significant determinants of the HDI, and it has a higher impact on middle-income countries, which can even make it a development tool [68]. Furthermore, Duranton (2014) argues that for both developed and developing countries, there is a positive impact of the city's size on the income levels, which is small for both cases, but higher for the developing countries [64]. Likewise, as the Western Balkan countries are less developed than the EU countries, they are facing a higher impact of urbanization. Urbanization is a natural part of the development process, and urban areas may be the core of human capital spillovers; they provide more opportunities for greater income levels and greater access to education and health systems, resulting in higher standards of living, allowing the conclusion that cities tend to perform better in terms of both economic and social development as compared to rural areas $[31,63,67]$. However, it is crucial to emphasize the importance of the creation of adequate planning policies that aim to achieve urban sustainability so that the process of urbanization is consistent with the principles of sustainable development $[69,70,76]$.

\section{Conclusions, Limitations, and Recommendations}

In the latest decades, economic development has been a topic of interest for researchers and policymakers across the nations. Following Akçay (2006), this paper tests the impacts of corruption, economic freedom, and urbanization on economic development [31]. Even though economic development is a widely studied topic, similar types of research for the Western Balkan countries or comparative analyses between the Western Balkans and the EU countries are limited in number $[4,10,11]$.

On average, the Western Balkan countries belong in the tier of the countries that have high human development, while the EU countries belong in the tier of the countries that have very high human development. Regarding corruption levels, the Western Balkan countries are more corrupt than the EU countries, as the latest ones have CPI scores nearly twice as high as those of the Western Balkans [21]. Considering economic freedom, the ratings of the Western Balkans are below those of the EU countries. None of the countries that are part of the EU have economic freedom index scores of less than 60, whereas none of the Western Balkan countries have index scores of less than 50 [22]. Taking into account the urbanization, on average for the EU countries, urban population growth rates vary from $0.2 \%$ to $0.5 \%$, while the Western Balkans mostly have growth rates of $0.2 \%$ and $0.3 \%$. In general, the ratings of the Western Balkans are below those of the EU countries [25].

The empirical results suggest a negative relationship between corruption and economic development, a positive relationship between economic freedom and economic development, and a positive relationship between urbanization and economic development for both the Western Balkans and the EU countries. In both cases, these impacts are significant at all levels of significance $(1 \%, 5 \%$, and $10 \%$ ); however, the magnitude of the impact is greater for the Western Balkans for each of the chosen independent variables, suggesting that the impact of corruption is more destructive in the Western Balkans, while they benefit more from economic freedom and urbanization as compared to the EU countries. The outcomes of the empirical analysis are in agreement with the reviewed literature.

Based on the availability of the data, the period chosen for this paper restricts the empirical analysis to the years after 2009. Additionally, the empirical results suggest that, in general, corruption causes worse conditions in both groups of countries, while these countries benefit from economic freedom and urbanization. However, in this paper, it is not shown whether the impact of the chosen independent variables is restricted to any component of the HDI in particular. Such an investigation is left open for further studies in the future. In addition, this paper focuses on the impact that economic freedom as a whole has on economic development; thus, in other studies, the components of economic freedom may be taken into consideration to find out if the relationship is restricted to any component in particular.

Regarding corruption, countries and societies of both the Western Balkans and the EU must fight to annihilate this ruthless force, or otherwise, people are going to suffer the consequences. The respective governments should take all the needed measurements to combat corruption, such as preventive and 
repressive actions. The increased responsiveness of government bodies, effective law enforcement, strong auditing agencies, and cutting of the international ties with countries that are considered highly corrupt may be the answer for combating corruption [80]. However, specific and detailed studies should be conducted to be able to find reforms that would work best for fighting corruption, because what works for the Western Balkans may not work for the EU countries.

Since the relationship between economic freedom and economic development is a positive one for both cases, the Western Balkans and the EU countries should make sure to boost the positive effects. Improvements in property rights, further removal of barriers that restrict trade and transactions, higher incentives to encourage entrepreneurship, and more support for economic activities by the government tend to lead to higher standards of living. Chang (2007) mentions that policies directly derived from the experiences of developed countries are likely to fail in developing countries; thus, studies should be conducted to find out which reform is best for each group of countries [58].

Lastly, for countries to benefit from urbanization and to overcome any losses that it may bring, the creation of urban planning policies is important $[69,70,76]$. Different planning policies may derive different results. Thus, for the countries involved, it is important to find out which policy works best for them, to implement it, and to ensure that this policy will help them to continue benefiting from urbanization and even to gain more from it in the future. To do so, specific studies should be conducted. Still, if countries need to enhance their economic performance, the collaboration among academia, government, business, and civil society is of great importance [81].

Author Contributions: Conceptualization, N.F., E.H., M.P., I.G.R. and A.B., methodology, N.F. and E.H.; software, N.F. and E.H., validation, N.F., E.H., M.P., I.G.R. and A.B.; formal analysis, N.F. and E.H.; investigation, N.F., E.H., M.P., I.G.R. and A.B., resources, N.F., E.H., M.P., I.G.R. and A.B.; data curation, N.F. and E.H.; writing-original draft preparation, N.F., E.H., M.P., I.G.R. and A.B.; writing-review and editing, N.F., E.H., M.P., I.G.R. and A.B.; visualization, N.F., E.H., M.P., I.G.R. and A.B.; supervision, N.F., E.H., M.P., I.G.R. and A.B.; project administration, E.H. All authors have read and agreed to the published version of the manuscript.

Funding: This research received no external funding.

Conflicts of Interest: The authors declare no conflict of interest.

\section{References}

1. EDUCBA. Accounting Fundamentals: Economic Growth Versus Economic Development. 2020. Available online: https://www.educba.com/economic-growth-vs-economic-development/ (accessed on 30 May 2020).

2. Drucker, P.F. Landmarks of Tomorrow: A Report on the New "Post-Modern" World; Transaction Publisher: Piscataway, NJ, USA, 2011.

3. Al-Hilani, H. HDI as a Measure of Human Development: A Better Index than the Income Approach? J. Bus. Manag. 2012, 2, 24-28. [CrossRef]

4. Hysa, E. Corruption and Human Development: Correlation in Western Balkan Countries. EuroEconomica 2011, 30, 148-157.

5. Ruiz, V.R.L.; Peña, D.N.; Navarro, J.; Grigorescu, A. Human development European city index: Methodology and results. Rom. J. Econ. 2014, 17, 72-87.

6. Lashmar, H. UNA-UK: SDGs-The Human Development Index. 2018. Available online: https://www. sustainablegoals.org.uk/human-development-index-better-indicator-success/ (accessed on 25 April 2020).

7. Adriana, G.; Marioara, I.; Octavian, B.A. Regional Development Policy in the EU and Romania-State-of-the-Art and Future Developments; Ovidius University Annals Economic Sciences Series; Ovidius University Press: Constanta, Romania, 2012; p. 272.

8. Gheorghe, Z.; Valentina, V.; Anca, C. Sustainable Development Challenges and FDI Impact in Host Countries; The Annals of the University of Oradea; University of Oradea: Oradea, Romania, 2012; p. 444.

9. Grigorescu, A.; Dincă, G. Link between Sustainable Development and Globalization of Contemporary Economy. Studia Universitatis "Vasile Goldiş" Arad Ser. Ştiinţe Econ. 2014, 24, 11-24.

10. Hysa, E. Corruption and Human Development: Albania and EU-27. Soc. Stud. 2011, 5, 43-53.

11. Mazllami, J. The Impact of Human Development in Corruption Mitigation: A Comparative Analysis between Macedonia and Albania. Econ. Aziend. Online 2019, 10, 191-202. 
12. United Nations. United Nations Development Program: Human Development Reports. 2019. Available online: http://hdr.undp.org/en/content/human-development-index-hdi (accessed on 30 May 2020).

13. Rădulescu, I.G. Duality of World Economy, Duality of World Economy Collection; Petroleum-Gas University of Ploiesti Publishing House: Ploiesti, Romania, 2007.

14. Elbegdorj, T. Embassy of Mongolia: “Mongolian Transition to Democracy and Lessons". 2014. Available online: http://embassyofmongolia.co.uk/?p=353\&lang=mn (accessed on 22 May 2020).

15. Profiroiu, M.; Andrei, T.; Popescu, G.; Profiroiu, A. Local Governance and Corruption. Transylv. Rev. Adm. Sci. 2006, 2, 62-68.

16. Raimi, L.; Suara, I.B.; Fadipe, A.O. Role of Economic and Financial Crimes Commission (EFCC) and Independent Corrupt Practices \& Other Related Offences Commission (ICPC) at Ensuring Accountability and Corporate Governance in Nigeria. J. Bus. Adm. Educ. 2013, 3, 105-122.

17. Zaman, G.; Ionescu, L. The Impact of International Economic Crises on Corruption in Romania. Econ. Comput. Econ. Cybern. Stud. Res. 2014, 48, 1-16.

18. Munir, Q. Corruption, Size of Government, and Economic Growth: Evidence from Global Data. In Handbook of Research on Globalization, Investment, and Growth-Implications of Confidence and Governance; IGI Global: Hershey, PA, USA, 2015; pp. 155-175.

19. Mungiu-Pippidi, A.; Dadašov, R. Measuring control of corruption by a new index of public integrity. Eur. J. Crim. Policy Res. 2016, 22, 415-438. [CrossRef]

20. Zaman, G.; Ionescu, L. Fighting Corruption Generated By Accounting. Case Study Romania. Econ. Comput. Econ. Cybern. Stud. Res. 2016, 50.

21. Transparency International. Corruption Perceptions Index: Overview. 2019. Available online: https: //www.transparency.org/research/cpi/overview (accessed on 22 May 2020).

22. Heritage Foundation. Heritage: All Index Data. Available online: https://www.heritage.org/index/about (accessed on 22 May 2020).

23. Cambridge Dictionary. Cambridge University Press: Urbanization. 2020. Available online: https://dictionary. cambridge.org/dictionary/english/urbanization (accessed on 30 April 2020).

24. United Nations. UN DESA: News. 2018. Available online: https://www.un.org/development/desa/en/news/ population/2018-revision-of-world-urbanization-prospects.html (accessed on 30 April 2020).

25. World Bank. World Bank Indicators: Urban Population Growth. 2018. Available online: https://data. worldbank.org/indicator (accessed on 12 May 2020).

26. Transparency International. Focus Areas: What is Corruption? 2018. Available online: https://www. transparency.org/what-is-corruption\#costs-of-corruption (accessed on 12 May 2020).

27. North, D. The New Institutional Economics and Development; EconWPA: St. Louis, MO, USA, 1993.

28. Akhter, S.H. Is globalization what it's cracked up to be? Economic freedom, corruption, and human development. J. World Bus. 2004, 39, 283-295. [CrossRef]

29. Asongu, S. Globalization (fighting), corruption and development: How are these Phenomena Linearly and Nonlinearly related in Wealth Effects? J. Econ. Stud. 2014, 41, 346-369. [CrossRef]

30. Nielsen, M.; Haugaard, J. Democracy, Corruption, and Human Development. 2000. Available online: https://hip.lisboa.ucp.pt/edocs/cde/2004_6333.pdf (accessed on 30 April 2020).

31. Akçay, S. Corruption and Human Development. Cato J. 2006, 26, 29-48.

32. De Mendonça, H.F.; Da Fonseca, A.O. Corruption, income, and rule of law: Empirical evidence from developing and developed economies. Braz. J. Politi. Econ. 2012, 32, 305-314. [CrossRef]

33. Mariyono, J. Corruption and Welfare: A Simple Econometric across Countries Analysis. Econ. J. Emerg. Mark. 2012, 4, 63-75.

34. Letaio, A. Corruption and the Environment. J. Soc. Econ. 2016, 5, 1-5. [CrossRef]

35. Hysa, E.; Çela, A. Relationship between Governance and Human Development in European Countries: Panel Regression Analysis. In Proceedings of the IAI Academic Conference, Rome, Italy, 11-17 August 2019; pp. 60-71.

36. Mansi, E.; Hysa, E.; Panait, M.; Voica, M.C. Poverty-A Challenge for Economic Development? Evidences from Western Balkan Countries and the European Union. Sustainability 2020, 12, 7754. [CrossRef]

37. Peyton, K.; Belasen, A. MPRA: The Case for Human Development: A Cross-Country Analysis of Corruption Perceptions. 2010. Available online: https://mpra.ub.uni-muenchen.de/31385/1/MPRA_paper_31385.pdf (accessed on 30 April 2020). 
38. Adhikari, S.H. NASC's Document Management System: Geography, Human Development, and Corruption: Does Corruption Vary Across Regions? 2015. Available online: https:/dms.nasc.org.np/sites/default/ files/documents/Geography\%2C\%20Human\%20Development $\% 2$ C $\% 20$ and\%20Corruption.pdf (accessed on 30 April 2020).

39. Akhbari, R.; Nejati, M. The effect of corruption on carbon emissions in developed and developing countries: Empirical investigation of a claim. Heliyon 2019, 5, e02516. [CrossRef]

40. Popescu, L.-M.; Dutulescu, S.; Nisulescu-Ashrafzadeh, I. Corruption Phenomenon in European Union. Eur. J. Bus. Manag. Res. 2019, 4, 1-7. [CrossRef]

41. Sarabia, M.; Crecente, F.; Del Val, M.T.; Giménez, M. The Human Development Index (HDI) and the Corruption Perception Index (CPI) 2013-2017: Analysis of social conflict and populism in Europe. Econ. Res. Ekon. Istraživanja 2020, 33, 2943-2955. [CrossRef]

42. Heckelman, J.C.; Powell, B. Corruption and the Institutional Environment for Growth. Comp. Econ. Stud. 2010, 52, 351-378. [CrossRef]

43. Egger, P.; Winner, H. Evidence on corruption as an incentive for foreign direct investment. Eur. J. Politi. Econ. 2005, 21, 932-952. [CrossRef]

44. Keisuke, O.; Sovannroeun, S. MRPA: How Does Corruption Influence the Effect of Foreign Direct Investment on Economic Growth? 2010. Available online: https://mpra.ub.uni-muenchen.de/27572/1/MPRA_paper_ 27572.pdf (accessed on 30 May 2020).

45. Colombato, E. Why is Corruption Tolerated? Rev. Austrian Econ. 2003, 16, 363-379. [CrossRef]

46. Méon, P.-G.; Weill, L. CORE: Is Corruption an Efficient Grease? 2008. Available online: https://core.ac.uk/ download/pdf/6659695.pdf (accessed on 30 May 2020).

47. Leff, N.H. Economic Development Through Bureaucratic Corruption. Am. Behav. Sci. 1964, 8, 8-14. [CrossRef]

48. Fernández-Torres, Y.; Gutiérrez-Fernández, M.; Ramajo-Hernández, J. Business regulation and economic growth: The indirect effect of corruption in latin america and the caribbean. J. Dev. Entrep. 2018, 23, 1850003. [CrossRef]

49. Hoinaru, R.; Buda, D.; Borlea, S.N.; Văidean, V.L.; Achim, M.-V. The Impact of Corruption and Shadow Economy on the Economic and Sustainable Development. Do They "Sand the Wheels" or "Grease the Wheels"? Sustainability 2020, 12, 481. [CrossRef]

50. Jiang, T.; Nie, H. The stained China miracle: Corruption, regulation, and firm performance. Econ. Lett. 2014, 123, 366-369. [CrossRef]

51. Ahmad, E.; Ullah, M.A.; Arfeen, M.I. Does corruption affect economic growth? Lat. Am. J. Econ. 2012, 49, 277-305. [CrossRef]

52. Sen, A. Development as Freedom; Oxford University Press: Oxford, UK, 2011.

53. Wallich, H.C. The Cost of Freedom; Harper \& Bros: New York, NY, USA, 1960.

54. Grubel, H.G. Economic Freedom and Human Welfare: Some Empirical Findings. Cato J. 1998, 18, $287-304$.

55. Madan, A. The Relationship between Economic Freedom and Socio-Economic Development. Univ. Ave. Undergrad. J. Econ. 2002, 7, 1-56.

56. Claessen, S.; Bellavitis, N. University of Rotterdam: Does Economic Freedom Stimulate Human Development? An Empirical Study on How Governments can Affect the Well-Being of Developing Countries. Available online: https: //www.eur.nl/sites/corporate/files/387349_NiccoloBellavitis_380725_SebastiaanClaessen_FinalPaper.pdf (accessed on 30 May 2020).

57. Vondrová, A.; Fifeková, E. Impact of Economic Freedom on Economic Development: A Nonparametric Approach to Evaluation. Eur. Sci. J. 2016, 12, 218-226.

58. Chang, H.-J. Institutional Change and Economic Development: An Introduction. In Institutional Change and Economic Development; United Nations University Press: New York, NY, USA, 2007; pp. 1-14.

59. Naanwaab, C. Does Economic Freedom Promote Human Development? New Evidence from a Cross-National Study. J. Dev. Areas 2018, 52, 183-198. [CrossRef]

60. Gehring, K. Who Benefits from Economic Freedom? Unraveling the Effect of Economic Freedom on Subjective Well-Being. World Dev. 2013, 50, 74-90. [CrossRef]

61. Corbi, R.B. The components of economic freedom, income and growth: An empirical analysis. Estud. Econômicos (São Paulo) 2007, 37, 515-545. [CrossRef]

62. Graafland, J. When Does Economic Freedom Promote Well Being? On the Moderating Role of Long-Term Orientation. Soc. Indic. Res. 2019, 149, 127-153. [CrossRef] 
63. Njoh, A.J. Urbanization and development in sub-Saharan Africa. Cities 2003, 20, 167-174. [CrossRef]

64. Duranton, G. The World Bank: Growing through Cities in Developing Countries. 2014. Available online: http://documents.worldbank.org/curated/en/727191468326108729/Growing-through-cities-in-developingcountries (accessed on 30 May 2020).

65. Bertinelli, L.; Zou, B. Does Urbanization Foster Human Capital Accumulation? J. Dev. Areas 2008, 41, 171-184. [CrossRef]

66. Odugbesan, J.A.; Rjoub, H. Relationship Among Economic Growth, Energy Consumption, $\mathrm{CO}_{2}$ Emission, and Urbanization: Evidence From MINT Countries. Sage Open 2020, 10, 2158244020914648. [CrossRef]

67. Huang, G.; Jiang, Y. Urbanization and Socioeconomic Development in Inner Mongolia in 2000 and 2010: A GIS Analysis. Sustainability 2017, 9, 235. [CrossRef]

68. Mayer-Foulkes, D. Divergences and Convergences in Human Development. Indian J. Hum. Dev. 2012, 6, 175-224. [CrossRef]

69. Liu, S.; Zhang, P.; Jiang, X.; Lo, K. Measuring sustainable urbanization in China: A case study of the coastal Liaoning area. Sustain. Sci. 2013, 8, 585-594. [CrossRef]

70. Sabyasachi, T. Munich Personal RePEc Archive: Urbanization and Human Development Index: Cross-Country Evidence. 2019. Available online: https://mpra.ub.uni-muenchen.de/97474/1/MPRA_paper_ 97474.pdf (accessed on 25 April 2020).

71. Moore, M.; Gould, P.; Keary, B.S. Global urbanization and impact on health. Int. J. Hyg. Environ. Health 2003, 206, 269-278. [CrossRef] [PubMed]

72. Eckert, S. Urbanization and Health in Developing Countries: A Systematic Review. World Health Popul. 2014, 15, 7-20. [CrossRef]

73. Szabo, S. Urbanization and Food Insecurity Risks: Assessing the Role of Human Development. Oxf. Dev. Stud. 2016, 44, 28-48. [CrossRef]

74. Dociu, M.; Dunarintu, A. The Socio-Economic Impact of Urbanization. Int. J. Acad. Res. Account. Financ. Manag. Sci. 2012, 2, 47-52.

75. Martínez-Zarzoso, I.; Maruotti, A. The impact of urbanization on $\mathrm{CO}_{2}$ emissions: Evidence from developing countries. Ecol. Econ. 2011, 70, 1344-1353. [CrossRef]

76. Mutuku, C. Business Economics: Urbanization in Developing Countries. 2018. Available online: https: //www.grin.com/document/432475 (accessed on 22 April 2020).

77. Hysa, E. Impact of Cultural Diversity on Western Balkan Countries' Performance. J. Ethn. Cult. Stud. 2020, 7, 20-40. [CrossRef]

78. Lopez, J. Corruption and its Effect on Economic Development in Chile, Mexico and Brazil. Gov. Political Sci. J. Unlv. 2019, 6, 4.

79. Unicef: Children in an Increasingly Urban World. 2012. Available online: https://www.unicef.org/sowc2012/ pdfs/SOWC-2012-Chapter-1-Children-in-an-increasingly-urban-world.pdf (accessed on 22 May 2020).

80. Transparency International. Transparency International News: How to stop Corruption: 5 Key Ingredients. 2016. Available online: https://www.transparency.org/en/news/how-to-stop-corruption-5-key-ingredients (accessed on 22 May 2020).

81. Hysa, E.; Kruja, A.D.; Rehman, N.U.; Laurenti, R. Circular Economy Innovation and Environmental Sustainability Impact on Economic Growth: An Integrated Model for Sustainable Development. Sustainability 2020, 12, 4831. [CrossRef]

Publisher's Note: MDPI stays neutral with regard to jurisdictional claims in published maps and institutional affiliations.

(C) 2020 by the authors. Licensee MDPI, Basel, Switzerland. This article is an open access article distributed under the terms and conditions of the Creative Commons Attribution (CC BY) license (http://creativecommons.org/licenses/by/4.0/). 